Volume 2 Issue 2, July-December 2021: pp. 137-150.

Indonesia Private Law Review.

Law Faculty, Universitas Lampung,

Bandar Lampung, Indonesia.

P-ISSN: 2723-259X E-ISSN: 2745-9284

https://jurnal.fh.unila.ac.id/index.php/iplr

\title{
THE LAWS PROTECTING CHILD WITNESSES IN GIVING EVIDENCE: HARMONIZATION BETWEEN MALAYSIAN LAWS AND AS-SHARIA
}

\author{
Mohamad Ismail Bin Mohamad Yunus', Nik Rahim Nik Wajis², \\ Mualimin Mochammad Sahid ${ }^{3}$, Nurliyana Shahira Baharli ${ }^{4}$ \\ ${ }^{1}$ International Islamic University Malaysia, Malaysia, ismailmy@iium.edu.my \\ ${ }^{2}$ Islamic Science University of Malaysia, Malaysia, drnikrahim@usim.edu.my \\ ${ }^{3}$ Islamic Science University of Malaysia, Malaysia, mualimin.sahid@usim.edu.my \\ ${ }^{4}$ Islamic Science University of Malaysia, Malaysia, liyanabaharli14@gmail.com
}

\section{Submitted: July 14, 2021; Reviewed: July 29, 2021; Accepted: August 4, 2021}

DOI: 10.25041/iplr.v2i2.2401

\begin{abstract}
Since issues of child abuse and other crimes against children have been brought to the public's attention through the media, this article considers to highlight one of the issues relating to the protection of child. The issue of the laws protecting child witnesses in giving evidence will come into the discussion. This paper considers the issue of corroboration of the child witness in the aspects of sworn and unsworn statements to determine whether the evidence given by children will be relevant and admissible in Courts. In tackling the issues, the research methodology applied by the authors is by analyzing and evaluating the decided cases and studying the substantive laws procedure in protecting child witnesses in giving testimony in Courts. The expectation findings of this paper are to harmonize between Malaysian and Islamic law relating to the protection of child witnesses in giving evidence in the court of law. After having observed the conflicts or the problems that had stem out of the current laws and procedures governing child witnesses as to the remedies, the final part of the article proposed some solutions and recommendations from the Islamic point of view.
\end{abstract}

Keywords: Child Witness, Child Act 2001, Evidence of Child Witness Act 2007, Evidence Act 1950, Sexual Offences against Children 2017, Islamic Law of Evidence \& Procedure.

\section{A. Introduction}

During the last decade, a large body of child witness research has changed the way child witnesses are perceived and treated by the legal system. Young children are becoming more widely accepted as reliable sources of information. However, there is evidence that children are suggestible under certain conditions. ${ }^{1}$ Previously, a child witness in sexual abuse who was also the victim also suffered

\footnotetext{
1 Andrea N. Welder, "Sexual Abuse Victimization and the Child Witness in Canada: Legal, Ethical, and Professional Issues for Psychologists," Canadian Psychology 41, no. 3 (2000): 160-173, https://doi.org/10.1037/h0086866.
} 
stress, trauma and emotional breakdown in giving evidence in court. ${ }^{2}$ Since issues of child abuse and other crimes against children have been brought to the public's attention through the media, there has been an uproar and growing public concern about child protection. In August 2002, Child Act 2001 was enacted as its prime measure to fulfill its obligation under the CRC, wherein one of its objectives is to provide for a child-friendly procedure before the court for children. On 30 August 2007, in light of the passing of the Child Act 2001, the Evidence of Child Witness Act 2007 was gazette to govern all procedural laws about the evidence given by a child in a court trial. ${ }^{3}$

The issue of reliability of the testimony given by child witnesses will come into the discussion. Despite the fact that children testifying in court are thought to be more honest than adults, their poor memory, communication skills, and greater suggestibility may make them less reliable witnesses than adults. ${ }^{4}$ This is often associated with the tendency to experience difficulty in clarifying what had happened either due to their lack of comprehension or given limited vocabulary. Moreover, they have difficulties in remembering the specific dates, times and events of the crime. Thus, we need to look into the history of evidence by a child witness in Malaysia that have been actively promoted by the United Nations Children Fund (UNICEF) through the Convention on Rights of Children (CRC). Malaysia became one of the countries sanctioned the CRC in 1995, with some reservations made to suit the Federal Constitution. ${ }^{5}$

It is undeniable that giving testimony against one's next-of-kin or someone they trusted in a rape or incest is undoubtedly not easy for children. Apart from that, it is so embarrassing for the victim to recall and relate the experience of rape to other strangers in court. Such difficulty can be seen in the case of Yusaini Mat Adam v. $P P,{ }^{6}$ where the accused was charged with raping his stepdaughter aged ten years eight months. The victim gave evidence when she was 11 years old. The judge described her condition as unstable in giving testimony where sometimes the victim cried when she was related to what had happened, sometimes she turned pale, and sometimes she refused to speak. The court had to postpone the proceedings several times to calm her down before she testified. The judge further stated that she seemed to be afraid of the deputy public prosecutor, the counsel for the defense and the accused. ${ }^{7}$ Similarly, in the case of Sidek bin Ludan $v . P P,{ }^{8}$ a child aged nine years ten months is raped by her neighbors and testified to the court when she was ten years six months. The judge described that the victim was under great difficulty in giving testimony. She was uneasy whenever she was asked a question regarding the incident between her and the accused.

Concerning these two cases, it is observed that the adversarial system has put much difficulty on children in giving direct evidence in court. This problem can be countered with a change in the procedure of child witnesses in giving evidence. According to experts, a strong initial interview is one of the best predictors of solid kid witness evidence. In tum, a thorough and accurate account reduces the likelihood of the child's account being distorted during cross-examination. ${ }^{9}$ The rule that

\footnotetext{
${ }^{2}$ Sarah Caprioli and David A. Crenshaw, "The Culture of Silencing Child Victims of Sexual Abuse: Implications for Child Witnesses in Court," Journal of Humanistic Psychology 57, no. 2 (2016): 9, https://doi.org/10.1177/0022167815604442.

${ }^{3}$ Norbani Mohamed Nazeri, "Protecting Child Victims in Malaysia," in Support for Victims of Crime in Asia, ed. Wing-Cheong Chan, 1st ed. (Oxfordshire: Routledge Publication, 2008), 291.

4 Charles Montaldo, "Child Witnesses: Honest but Less Reliable," ThoughtCo, 2019, https://www.thoughtco.com/child-witnesses-honest-but-less-reliable-972221.

${ }^{5}$ Aminuddin Mustaffa and Salleh Kamaliah, "Evidence by Child in Criminal Proceedings in Malaysian Courts: A Study on Post Ratification of Convention of Rights of Child," Malaysian Current Law Journal 6 CLJ (2010): 127.

${ }^{6}$ [1999] 1 MLJ 158.

${ }^{7}$ Nazeri, "Protecting Child Victims in Malaysia."

8 [1995] 1 MLJ 178.

${ }^{9}$ Martine B. Powell, "Improving the Reliability of Child Witness Testimony in Court: The Importance of Focusing on Questioning Techniques," Current Issues in Criminal Justice 17, no. 1 (2005): 137-143, https://doi.org/10.1080/10345329.2005.12036342.
} 
governs the principle of evidence is governed under the Evidence Act 1950. Still, child witnesses give evidence is governed under the Evidence of Child Witness Act 2007. The object of the Evidence of Child Witness Act 2007 is to provide special procedures of giving evidence in ensuring the child feels comfortable without being traumatized and eventually eases the trial process itself. It is pointed out that the procedure in protecting child witnesses under Evidence of Child Witness 2007 can be narrowed to three scope of discussion, namely, the court setting, the court procedure and also other unique features of the court proceedings. ${ }^{10}$

The discussion will begin with the definition of the child witness in the Malaysian law context, followed by an explanation relating to 2 (two) categories of child witnesses. The first category is when the child victim themselves is directly involved in the case, such as sexual assault. The second category is the child as the bystander of an offence, who is not directly involved or the victim, however, they have witnessed the occurrence of the offence directly. Therefore, they can become competent witnesses and give testimony, often the most crucial part of the prosecution's case. ${ }^{11}$

\section{B. Discussion}

\section{Procedure in Protecting Child Witnesses in Giving Evidence in Court.}

The Evidence of Child Witness Act 2007 provides the special court sitting for the child in giving evidence regarding the court setting. To a child's perception, a regular courtroom is a unique place to them, with a judge who uses odd words, a costume with a hammer in his hand. By that perception, an issue arose on how a child would survive going through the proceeding alone? The best way to solve this issue, is by making the courtroom friendlier and not too formal to make the child feel more supported. Apart from that, the child can be seen and heard comfortably by rearranging the court setting itself. In addition, the Evidence of Child Witness Act 2007 provides the high-tech equipment for the child to testify. By referring to s.3 (2) of the Evidence of Child Witness Act 2007, the examination of a child witness can be conducted other than the witness box, where the judge may use his discretion by permitting the child witness to testify in a separate room, then that area will be considered part of the courtroom.

Furthermore, s.4 of the Evidence of Child Witness 2007 explains that the court must ensure the setting up of the particular screen to prevent child witnesses from seeing and being seen by the accused if the child intends to testify in a courtroom. Since there is no provision on how the screen needs to be set up, it is permissible as long as the arrangement can prevent a child from seeing or being seen by the accused. This statute also allows the child witness to give evidence through livelink from a particular place other than the courtroom or video recording. ${ }^{12}$

Regarding the court procedure, Evidence of Child Witness 2007 provides the setting of video or tape recording to give evidence by a child witness in creating warm proceedings. It is recommendable for video technology to be used in examinations. As stated in s. 6 (1) of the Evidence of Child Witness Act 2007, if the video recording is being used in giving testimony, such video recording shall be admitted as evidence of examination in chief. Still, it is subjected to the provision of the Evidence Act 1950. ${ }^{13}$

In light of s. 6 (6) of the Evidence of Child Witness Act 2007, the effect of such video evidence shall be treated as if it was given through direct oral evidence in examination in chief. Upon tendering the video, the child may be examined in chief on matters that have not been adequately dealt with in the recorded testimony by s. 6 (4) of the Evidence of Child Witness 2007. The other

\footnotetext{
${ }^{10}$ Mustaffa and Kamaliah, "Evidence by Child in Criminal Proceedings in Malaysian Courts: A Study on Post Ratification of Convention of Rights of Child."

${ }^{11}$ ss. 118 and 133A of the Evidence Act 1950.

12 Sol Gothard, "The Admissibility of Evidence In Child Sexual Abuse Cases," Child Welfare 66, no. 1 (1987): 13-24.

${ }^{13}$ s. 6 (1) of the Evidence of Child Witness Act 2007.
} 
court procedure in protecting child witnesses in giving evidence provides a live link between the courtrooms where the party is present and a separate room where the child is situated. According to s. 5 (1) of the Evidence of Child Witness 2007, if the live link evidence is given elsewhere, i.e. outside the courtroom, it will be considered as given in the courtroom itself. It must be noted that is also by the court declaring such a separate location to be deemed as part of the presiding courtroom. By s. 9 of the Evidence of Child Witness 2007, the parent or guardian also may accompany the child witness when he gives the evidence from a separate location. The court also can make orders for the specific member of the court, such as staff or interpreter, to be presented together with the child witness at such location under s. 5 (2) of the Evidence of Child Witness 2007. It is stated that if the child witness gives the evidence through live-link, the effect of this evidence present the child as if they are in a normal courtroom as stated in s. 6 of the Evidence of Child Witness 2007. In addition, the question must be put forward about child witnesses through an interpreter or any authorized intermediary appointed by the court. In contrast, the examination of a witness in the normal proceeding is conducted by the parties in which those parties directly posed the question to the respective witness. ${ }^{14}$

Regarding the other special feature of a court proceeding, Evidence of Child Witness 2007 removes publicity to protect the child witness and their safety in giving the witness. According to s.14 (1) and 14 (2) of Evidence of Child Witness 2007, there is an express restriction of publication of background and details of child witnesses involving their name, addresses, educational institution, etc. This restriction is limited to his details and applied to publication through mass media or any electronic medium. In addition, Evidence of Child Witness 2007 expressly stated the word "shall", which reflects total prohibition on the publicity of child witness data.

Compared to the English law expressly stated the word "may" in its statute, this showed that the publicity of child witness might be allowed if permitted by the court. In Malaysia, if the person fails to comply with the provision under s. 14 (1) and 14 (2) of Evidence of Child Witness 2007 a fine of up to RM10.000.00 or imprisonment for up to five years, or both, may be imposed under Section 16 (3) of the Evidence of Child Witness 2007. Furthermore, the removal of formal attire is one of the other special features of the court proceeding. It is reported that removal of formal attire also includes removing robes of the judges, lawyers and prosecutors wherein the court are given the discretion to direct the wearing of jackets, coats, gowns, or other formal attire of a judge and court officers to be dispensed by s. 10 of the Evidence of Child Witness 2007, in creating warm and friendly court proceeding. Other than Evidence of Child Witness 2007, the Child Act 2001 also provides inadequate protection for child witnesses as stated in s. Eighty-five of the Child Act 2001, there must be an appropriate arrangement for the child while waiting before or after attendance in court. Firstly, the child witness must be separated from the accused person. Secondly, the child witness, who is a girl, must be in the safe custody of the woman. Thirdly, the picture of a child witness must be restrained from being recorded in any manner on tape or film or by any electronic medium.

Furthermore, in her studies in the year 2020, Melton reported that the way to approach the child witness is; first, the interviewer, i.e. police officer, interpreter or even lawyer, need to be careful on how to ask the questions. Leading questions and suggestive influence must be prevented because these will reduce the reliability of children's reports, resulting in false details about events that never occurred. In addition, the children can be interviewed from three to four years of age. As children grow older, their abilities become more similar to those of adults. The interviewers should use openended questions and let the child talk freely to avoid influencing the child in answering such questions. ${ }^{15}$

\footnotetext{
${ }^{14}$ Mustaffa and Kamaliah, "Evidence by Child in Criminal Proceedings in Malaysian Courts: A Study on Post Ratification of Convention of Rights of Child."

${ }^{15}$ G. B. Melton, “Children's Competency To Testify," Law and Human Behavior 5, no. 1 (1981): $73-85$.
} 


\section{Whether The Evidence Given By A Child Must Be Corroborated.}

The meaning of corroboration has been variously defined. Corroboration itself is questionable whether it is either necessary or desirable, because sometimes, even when there is strong corroborative evidence, less specific information may be required ${ }^{16}$. It has been said in the case of DPP v. Hester, ${ }^{17}$ that there is nothing technical in the idea of corroboration, while in Kilbourne's case, it said that the word corroboration by itself means no more than evidence tending to confirm other evidence. The corroboration rules were introduced and developed to ensure that the jury would determine cases appropriately to avoid convictions based on insufficient and unreliable evidence. In Malaysia, s. 134 of Evidence Act 1950 has laid down that "no particular number of witnesses shall, in any case, be required for the proof of any fact". This indicates that, if believed, the evidence of a single witness is sufficient to establish any act.

Besides that, the Courts may act on the testimony of a single witness, even though uncorroborated or upon duly proved documentary evidence without such testimony at all. On the other hand, this section enshrines the well-recognized legal maxim, "Testes ponderantur, nonnumerantur", which means the evidence must be weighed and not counted. ${ }^{18}$ The basis is that the court is concerned with the quality and not the quantity of the evidence. In Aziz Bin Muhammad Din v. $P P,{ }^{19} \mathrm{~A}$ court can and may act on the testimony of a single witness though uncorroborated. Unless statutes insist upon corroboration, courts should not insist on corroboration in cases the single witness itself requires that corroboration should be insisted upon as a rule of prudence - for example, a child witness or a witness whose evidence is that of an accomplice.

There is an exception to the general rule of s. 134 Evidence Act 1950, corroboration is required as a matter of law and practice. If the need for corroboration is required by law, it is mandatory. In other ways, a judge in deciding the case must consider whether the witness has been sufficiently corroborated by other evidence before the court can rely on his evidence. A clear example is mentioned in s. 133A of Evidence Act 1950, which provided that if a child gives unsworn evidence on behalf of the prosecution and the evidence is not corroborated, the accused shall not be liable based upon such evidence. However, corroboration as a matter of practice and prudence usually is derived from consistent judicial decisions, and it is not mandatory. It is only a rule of prudence where a judge exercises a reasonable caution in relying upon uncorroborated evidence of a witness, including children and complainants, in sexual cases. ${ }^{20}$

First and foremost, s. 118 of Evidence Act 1950, has laid down about a child witness. This section classifies all persons are competent to testify unless they are, among other things child of tender years. Concerning children of tender years, no actual age is fixed by law to determine whether they are barred from testifying. The Malaysian Courts generally perceive the testimony of a child as being unreliable before the court of law. The phrase "tender years" is mentioned in s. 118 of Evidence Act 1950 is not defined in the Evidence Act. Hence, the court was the one who can decide whether the child shall be a child of tender years. When describing tender years, the provision should be read in conjunction with the Child Act 2001, which defines "child" as a person under the age of eighteen years, and in relation to criminal proceedings as a person who has reached the age of criminal responsibility. ${ }^{21}$

\footnotetext{
${ }^{16}$ Martine B. Powell and Donald M. Thomson, "The Makings of a Reliable Interview with a Child Witness," Australian Educational and Developmental Psychologist 18, no. 2 (2001): 25-38, https://doi.org/10.1017/S081651220002839X.

17 [1972] 3 All ER 1056; 5 [1973] A.C 729.

${ }^{18}$ Habibah Omar, Siva Barathi Marimuthu, and Mazlina Mahali, Law of Evidence in Malaysia, 2nd ed. (Selangor: Sweet \& Maxwell, 2020): 38.

${ }^{19}$ Aziz Bin Muhammad Din v. PP [1996] 5 MLJ 473, 484-485.

${ }^{20}$ s. 133 A of Evidence Act 1950

${ }^{21}$ Omar, Marimuthu, and Mahali, Law of Evidence in Malaysia. Pg. 38.
} 
Furthermore, the Malaysian Courts have adopted the Indian precedent in Santosh Roy v. State of West Bengal, ${ }^{22}$ which held that a child's intellectual capacity to understand questions and give rational answers is the sole test of testimonial competency in construing tender age. In doing so, the Indian Courts often go beyond the child's age per se and scrutinize the child's background in accessing their intellectual capacity. Another example, in Tehal Singh and Ors. $v$ State of Punjab, ${ }^{23}$ the Supreme Court of India posited that the 13-year-old child witness was deemed not a tender age based on the capability to understand the significance of the oath and the necessity to speak the truth. Thus, it can be seen that the court used a few ways in interpreting the tender years of a child.

It is prudent to note that s. 133A of Evidence Act 1950 deals with the evidence of child witnesses. The provison of the simple Act in terms means that a conviction cannot stand on the uncorroborated evidence of an unsworn child witness. Thus, a child of a tender age who does not understand the nature of an oath but possesses sufficient intelligence to justify evidence and understands the nature of speaking the truth may give evidence before a court. However, this testimony will be regarded as unsworn testimony, which requires corroboration before it can be used to convict an accused. It is insufficient for the trial court to merely administer a warning on the dangers of so convicting as the amendment now makes it the rule of law, more explicitly, that the evidence of an unsworn child witness shall be corroborated. ${ }^{24}$

The fact that the child may understand questions and give rational answers does not necessarily mean that his evidence is reliable. This can be observed in the case of Chao Chong \& Ors v. PP, ${ }^{25}$ the court stated that "It is a matter of common knowledge that children at times may find it difficult to distinguish between reality and fantasy".

It shows that the court finds it difficult to distinguish between observation results and the results of imagination. Therefore, for a child who is considered competent to take an oath, the testimony of a child carries different weight depending on if it is a sworn or unsworn testimony. While in Tajudin Bin Salleh v. PP, ${ }^{26}$ it was held that s. 133A of Evidence Act 1950 must be read together with Section 118 of the Evidence Act 1950, which establishes the general competency of witnesses to satisfy the test of understanding the questions put to them. In practice, s. 133A of Evidence Act 1950 to act as to qualify to s. 118 of Evidence Act 1950, both sections affect a child of tender years in which the child shall not be prevented from comprehending the questions asked and the child could give sensible answers to questions asked. Thus, the court shall put simple questions to the child to test if the child can understand the nature of speaking the truth. This can be indicated whereby if the child answers the questions satisfactorily, the judge will certify that the child is competent to give evidence. ${ }^{27}$

In respect of child testimony, there are two things to consider. The first one is about sworn testimony. When a child gives sworn evidence in court, corroboration of the child's evidence is not mandatory. However, the court should administer a corroboration warning when assessing the sworn evidence of the child. Under s. 6 of the Oath and Affirmation Act 1949, this is empowered that witnesses must give evidence under oath. Under s. 8 of the Act, any immature person who ought not to be affirmed or taken oath can take evidence after a caution by the court to speak the truth, the whole truth, and nothing but the truth. ${ }^{28}$

\footnotetext{
22 AIR 1997 Cal 168

23 AIR 1979 SC 1347

${ }^{24}$ Eric Gertner, "The Unsworn Evidence Of Children And Mutual Corroboration," Osgoode Hall Law Journal 16, no. 2 (1978): 34.

25 [1960] MLJ 238

26 [2008] 1 MLJ 397.

${ }^{27}$ Nicholas Bala et al., "The Competency of Children to Testify: Psychological Research Informing Canadian Law Reform," International Journal of Children's Rights 18 (2010): 53-77, https://doi.org/10.1163/157181809X458544.

${ }^{28}$ ss. 6 and 8 of the Oath and Affirmation Act 1949.
} 
The law has been applied in the case of Public Prosecutor v. Gurdial Singh a/l Pretum Singh, ${ }^{29}$ the court held that an accused could be convicted of the offence even if some material evidence does not corroborate the sworn evidence of a child. One of the recent cases, the case of PP $v$. Thomas Hee Kein Vun, ${ }^{30}$ in which the court upheld the decision of the session court. The court, in this case, found out that the victim of 14 years old at that time she testified was capable of giving evidence under oath. Disregard medical evidence provided as corroboration. The court relied on the sworn evidence of the child. Thus, s. 133A of Evidence Act 1950 did not apply, and her testimony did not mandate corroborative evidence

However, the position on unsworn testimony, on the other hand, is entirely different. If the child does not understand the nature of an oath, he may give unsworn evidence provided that at least he understands the duty of speaking the truth if the child gives unsworn testimony, the proviso of s. 133A of Evidence Act 1950 states that a conviction based upon the unsworn evidence of the child which is not corroborated is illegal. Therefore corroboration is mandatory. This was illustrated in the case of Mohd Zuki v. PP, ${ }^{31}$ The witness was a young girl with an intellectual disability, and supposedly she should not be allowed to give evidence on oath. On appeal, the court held that the credibility of the child's evidence was doubtful and ought to be rejected since the evidence given was without corroboration.

The case of PP v. Asmad bin Akdim, ${ }^{32}$ also indicated that the accused raised issues on the complainant and gave unsworn evidence during the trial on appeal. The medical report and the chemist report do not corroborate the complainant's unsworn evidence. The court held that the allegation of rape by the victim was not corroborated by any other evidence as required under s.133A of Evidence Act 1950 and acquitted the accused. Based on the decided cases, in a situation where the evidence is not according to the requirement under s. 133A of Evidence Act 1950, the court may reject the evidence. ${ }^{33}$

Furthermore, since the law is developing day by day, the Sexual Offences against Children Act was established in 2017 to protect the child. Section 18 of the Act further strengthens the status quo regarding the status of unsworn testimony of a child witness that the court may convict a person based on the uncorroborated evidence of a child. This provision gives the discretion to the judge to convict on the uncorroborated testimony of a child victim. However, the proviso is silent regarding the requirement of a corroboration warning. ${ }^{34}$ This happens when the judge decides to convict based on unsubstantiated evidence. It is thus likely that the common law prudence requiring such warning would apply. ${ }^{35}$

It is noted that the introduction of this Act creates a dual rule regarding child witnesses. Under this Act, a child witness who is a victim does not require corroboration, but a child witness that is not a victim requires corroboration under the Evidence Act. It is unreasonable to create this double standard that his competency is immediately questioned because a child is not a victim. Due to the conflict between the two rules, the legal maxim of "Generalia specialibus non-derogant" shall apply whereby general law does not derogate from a specific law. Section 18 of the Sexual Offences against Children Act 2017 would prevail over s. 133A of Evidence Act 1950. However, the word "may" mentioned in s. 18 of Sexual Offences against Children Act 2017 give discretion to the court to convict on uncorroborated evidence.

\footnotetext{
29 [2012] 2 AMR 327.

30 [2019] MLJU 1415.

31 [2008] 1 MLJ 397

32 [2020]8 MLJ 21.

${ }^{33}$ Mustaffa and Kamaliah, "Evidence by Child in Criminal Proceedings in Malaysian Courts: A Study on Post Ratification of Convention of Rights of Child."

${ }^{34}$ Robyn Blewer, "Testing the Law and Testing a Child's Evidence: Nineteenth-Century Corroboration Reforms and Child Witness Testimony," Australian Historical Studies 51, no. 3 (2020): 279, https://doi.org/10.1080/1031461X.2019.1697304.

35 s. 18 Sexual Offences against Children Act 2017.
} 
It is observed that by having analyzed both the Evidence Act 1950 and the Sexual Offences against Children Act 2017, Malaysia's position on child witnesses is that both the sworn and unsworn testimonies are admitted in court upon proving competency. Still, the latter requires corroboration to implicate an accused, whereas the former does not. Children generation nowadays can convey accurate information without mixing fantasy and reality. Considering the position of the child evidence in different jurisdictions and scientific developments in how a child is just as capable as an adult in providing evidence, the mandatory corroboration requirement for unsworn testimony of a child in Malaysia has to be abolished. Child testimony need not be corroborated because they are reliable. Section 133A of the Evidence Act 1950 should be repealed because of its corroboration requirement about children of unsworn witnesses while s. 18 of the Sexual Offences against Children Act 2017 must be amended to ensure non-corroboration for all child witnesses.

\section{Islamic Perspective}

The provisions of laws relating to evidence given by a child witness in Islam in Malaysia can be seen in the Sharia Court Evidence (Federal Territory) Act 1997 ("SCEA 1997"). It can be referred to Section 3 (1) of the SCEA 1997, where it defines "child" as a person who has not attained the age of majority or baligh. Generally, a child lacks the competency to give evidence in Islam. A child lacks understanding and discerning power inherent in persons of tender years, thus preventing them from understanding the nature of certain events. Nevertheless, there are certain exceptions to the general rule. The evidence of a child may be accepted in some instances to preserve the rights of people. Hence, it is necessary to lighten the burden of the people and to disregard the general rules. Concerning the exception to the general rule, the Jurists have also referenced one of the Islamic legal maxims, which are Al-Masyaqqah Tajlibu Al-Taysir, with the meaning of hardship begets facility. The same issue arises under the Islamic law of evidence which is on whether or not the testimony of a child can be accepted in court. It can be seen in the past regarding the case of Prophet Isa (PBUH), a testimony was made by him when he was only an infant. As a result, such testimony has helped to clear his mother, Maryam, from adultery. Thus, it can be indirectly portrayed that the child can give evidence under Islamic law. However, people will find a way to argue that the Prophet Isa (PBUH) was a child who has been given a unique ability to speak while he still a baby during that time, unlike other normal babies. ${ }^{36}$

As far as children's evidence is concerned, the Muslim jurists did not concur on its admissibility. The Muslim jurists are unanimous in their opinion that before someone's testimony can be accepted, one of the conditions for the admissibility of evidence in Islamic law is the attainment of puberty or baligh. Reference shall be made to the s. 83 (1) of the SCEA 1997, which provides that all Muslims shall be competent to give shahadah or bayyinah as witnesses. They are agile, baligh, Adil, have a good memory and are not prejudiced.

Further, s 83 (4) of the same Act provides that a person who is not baligh or an unsound mind is competent to give bayyinah, but not competent to give syahadah. From the two above provisions, it can be summed up that one of the requirements to give testimony under the Islamic law of evidence is to attain the age of majority or baligh. In the case where the person is not yet baligh, they are competent to give evidence by way of bayyinah and can be accepted so long as there is no enmity between them. It is worth noting that the degree of syahadah is much higher than bayyinah, where the syahadah binds the court, but not the same will apply to bayyinah. But, it doesn't mean that the court will reject bayyinah in the first place. It is upon the court's discretion to accept bayyinah as evidence to be tendered depending on its strength.

It is necessary to compare and contrast Islamic law of evidence and Malaysian law of evidence.

\footnotetext{
${ }^{36}$ Mohd Shukri et al., "Should a Child Be Allowed to Give Evidence? The Position of Child Evidence under Civil and Islamic Laws in Malaysia," Munich Personal RePEc Archive, 2014, 1-24, https://mpra.ub.unimuenchen.de/60173/1/MPRA_paper_60173.pdf.
} 
The general rule under the Islamic provision is that the child lacks the competency to give evidence. Meanwhile, the provision of Malaysian evidence emphasizes that infancy does not render a witness incompetent. Secondly, the requirement to give testimony under Islam is attaining puberty of a child or baligh. Nevertheless, the child who can understand the questions put to them and the child's intellectual capacity to be accepted as those who can give testimony in the court under the Malaysian provision on evidence law. Thirdly, there is no specific requirement of corroboration on the evidence of a child under the SCEA 1997 in comparison with EA 1950.

Under s. 133A read together with s. 118 of the EA 1950, the evidence was given by child tender years, if given unsworn, must be corroborated, or if not, the accused shall not be liable to be convicted of the offence.

Fourthly, the degree of proof and evidence in Islam is not the same for every case, i.e. Hudud, Qisas, Ta'zir, to be agreed that degree to prove Hudud is heavier than the others, while the latter, as noted in criminal cases, is to prove beyond a reasonable doubt. Civil cases need to prove the balance of probabilities. Lastly, s. 86 of the SCEA 1997 provides the detailed requirement on the number of witnesses. This can also be supported with few verses in Al-Quran, such as Surah AL-Talaq verse 2, which talks about a person bringing forward two fair ('Adil) male witnesses to testify. Surah AlBaqarah verse 282 mentions that one male witness can testify but must present with two female witnesses. The two female witnesses must give reminders to each other.

The main concern under EA 1950 is the reliability of the witness. Even if only one witness comes forward to testify, but can satisfy the requirement provided by the court, then the court may tender the witness's testimony to the court. What's more, in the case, the evidence of that witness is in corroboration with other evidence. Hence, legally speaking, a child may be allowed to give evidence in some instances under both civil laws and Islamic laws, which are applicable in Malaysia, provided that all the requirements for the admissibility of such evidence have been fulfilled before the court. Nonetheless, no such provision is seen from EA 1950. ${ }^{37}$

\section{Suggestion}

Two forms of the solution have been proposed: a subjective approach to the unsworn evidence upholding the child's best interest and improving the procedure in the court's system by amending the law to suit current development and the needs of the children. Regarding the subjective approach to the unsworn evidence, the approach can be understood as derived from an individual's judgment or own experience about whether a specific outcome is likely to occur. It contains no formal calculations and only reflects the subject's opinions and experience rather than on data or computation.

Nevertheless, the approach will differ from person to person and contains a high degree of personal bias. From the given definition, a subjective approach is agreed to be made by the court, particularly the judge. It is of the view that entirely removing the child's unsworn evidence that requires mandatory corroboration seems too dangerous. Say in the situation where the judge can decide solely based on the unsworn evidence given by the child. It might inflict prejudice or unfairness on the accused. As noted, the court must determine if a child witness can either give sworn or unsworn evidence. To determine this, the court must conduct an inquiry process or preliminary examination against the children before they can testify in the court. After the inquiry or preliminary examination, if the court finds the child is competent and has an appropriate level of understanding, the court will allow him to give sworn evidence from the 'witness box'.

On the other hand, if the court finds the child does not satisfy the requisite competency but possesses a sufficient level of intelligence and understands the duty of speaking the truth, the court

\footnotetext{
${ }^{37}$ Shukri and Hassan.
} 
may allow him to give unsworn evidence from the 'dock'. ${ }^{38}$ It can be seen that the court had approached the unsworn evidence by assessing whether the child possesses a sufficient level of intelligence and understands the duty of speaking the truth. There is a need to discuss whether the approach to understanding the duty to speak the truth is relevant. The approach done by Scotland and Canada should be taken into consideration. Perhaps the two countries mentioned have the most liberal approaches toward allowing children to testify without demonstrating truth-lie competency.

Scotland prohibited any investigation into children's understanding of truth and lies in 2004. Meanwhile, in 2005, Canada adopted a similar ban, and all children fewer than 14 were asked to promise to tell the truth rather than administer a formal oath. ${ }^{39}$ The justification for the change in the law in Canada was that there is little or no relation between children's understanding of truth and lies and their honesty. There is substantial empirical evidence supporting this claim. Several studies have found that children's eyewitness performance is not related to their understanding of truth and lies. ${ }^{40}$

The laws in the United Kingdom also have gradually liberalized concerning child witnesses and have virtually abolished truth-lie competency requirements in the criminal courts. By 1991, the law required that testimony by children under 14 years of age be unsworn. By 1999, the only requirement for unsworn testimony was that the witness understands questions and be capable of giving understandable answers. ${ }^{41}$ It is fair to conclude that assessing a child's understanding of truth or lies has virtually no value in assessing the child's honesty and is likely to make matters worse. Indeed, recent research suggests that children with a developing understanding of truth and lies are better able to make false statements. ${ }^{42}$

In other words, it is more difficult for the child who does not know the difference between 'truth' and 'lie' to tell a lie. This finding should not be surprising because both understanding truth and lies and the ability to lie are related to children's cognitive development. Indeed, it can be seen that adults are probably the best liars, and they are, of course, quite capable of defining truth and lies. From all of the above provisions, it shall be agreed that the approach of the Malaysian Court regarding the understanding of the duty of speaking the truth is no longer relevant to the current development. ${ }^{43}$

Furthermore, the provision in South Africa under Chapter 2, Article 28 of the Republic of South Africa 1996 can be referred to. In s. (1) (d), it stated that "Every child has the right to be protected from maltreatment, neglect, abuse or degradation". Next, s. (1) (h) of the same Act provides that "Every child has the right to have a legal practitioner assigned to the child by the state, and at state expense, in civil proceedings affecting the child, if substantial injustice would otherwise result". Further, s. (2) states that "A child's best interests are of paramount importance in every matter concerning the child". It can be taken into consideration that South Africa heavily emphasizes all the above provisions and concerns about the child's interest and even enact specific Sections in their Constitution. Moreover, it can be supported with the case of Zorbas v. Zorbas, ${ }^{44}$

The case is regarding the custody of children. The mother had married another man. The former husband alleged the man has a bad attitude based on their child testimony. Interestingly, the court opined that if the child is incompetent, the judge will not reject it only because of its inadmissibility. Besides, the judge will act as the guardian of the child in the court and quoted, "It seems to me that

\footnotetext{
${ }^{38}$ Mustaffa and Kamaliah, "Evidence by Child in Criminal Proceedings in Malaysian Courts: A Study on Post Ratification of Convention of Rights of Child."

39 Caroline Keenan and Laura Hoyano, Child Abuse: Law and Policy Across Boundaries (Oxford: Oxford University Press, 2007). P. 321.

${ }^{40}$ Bala et al., "The Competency of Children to Testify: Psychological Research Informing Canadian Law Reform."

${ }^{41}$ Bala et al.

42 Elizabeth C. Ahern, Thomas D. Lyon, and Jodi A. Quas, "Young Children's Emerging Ability To Make False Statements," Developmental Psychology 47, no. 1 (2011): 61-66, https://doi.org/10.1037/a0021272.

${ }^{43}$ Mustaffa and Kamaliah, "Evidence by Child in Criminal Proceedings in Malaysian Courts: A Study on Post Ratification of Convention of Rights of Child."

441987 (3) SA 436 (W).
} 
the concept of guardianship involves a responsibility transcends the strictures of the law of evidence". Hence, it shall be agreed that to uphold the child's best interest, it is allowed to go beyond the law for the children's sake.

Besides, it can be referred to the United Nations Convention on the Rights of the Child 1989 (UNCRC 1989). ${ }^{45}$ As noted, Malaysia acceded to the UNCRC 1989 in 1995. The provision on the Article 3 (1) of the UNCRC 1989 is in the child's best interests. It provides that the child's best interests must be a top priority in all decisions and actions that affect children. Thus, it is essential to consider that the child's best interests shall be a primary consideration in all actions concerning children. Therefore, the Malaysian judiciary system is suggested to review this provision again in discussing the issue of children's best interest because it is time to step up in the law to protect the child known as a vulnerable and fragile human being. ${ }^{46}$

The second solution that has been proposed is to improve the procedure in the Court system by amending the law to suit current development and the needs of the children. Even though the Evidence of Child Witness Act 2007 (ECW 2007) provides for any special procedures to facilitate the child witness to testify in court. The procedures may have yet to be fully implemented throughout courts all over the country for various reasons, such as lack of suitable facilities. There are still rooms for improvement that need to be looked into in terms of implementation, facilities and manpower towards realizing what has been strongly urged by UNCRC $1989 .{ }^{47}$

The first procedure that needs to be improved is on the Court setting or arrangement of live-link. As mentioned earlier, all Courts must be prepared to accommodate all permitted modes for a child to testify in a criminal proceeding regarding the arrangement, high-technology facilities and manpower. Apart from that, it should include the mode of giving evidence vide live-link. The provision of ECW 2007 gives the idea that live-link can be applied not limited to the giving of evidence from a separate room of the same court building but also extended to any other locations apart from the court building, when necessary. For instance, the court may allow a child to give testimony from outside of the court, i.e. video live-link from his bed in the hospital, especially if the doctor recommends. Other than that, it can be considered where the child is placed under the shelter of a welfare house or probation school. In such instances, it is incredibly noteworthy for the court to ensure that the live link is available to accommodate the child's condition apart from protecting its identity from publicity. The suggestion to be proposed is that one specific section deals with the child's appointment date. For instance, it must be made earlier and before 14 days from the actual date of giving testimony. It is so unfortunate if it is found out that the children are ready to give testimony to the court. However, the court failed to accommodate it.

The second procedure is on the video or tape provided under s. 6 of the ECW 2007. This section allows for pre-recorded video evidence to be tendered in the court for a child witness. Nonetheless, the current wordings of this section are only limited to situations where a child is given the privilege to have his statement recorded earlier than the examination of his statement in court.

The recorded statement shall be admitted as evidence of examination in chief. However, this section does not include the video recorded during the interrogation stage to be part of such evidence. It shall be considered that video or tape recording was taken during an interrogation stage has some advantages. The first positive point is that the video recording offers practical first opportunity evidence of a very young or highly traumatized child, which the court might not be able to hear under normal circumstances of proceedings unless recorded as such. Pre-recorded video much before and outside the trial sessions can put the children at ease. The child might feel terrified and stressed to give testimony in court due to the traumatized experience. The second good point is that the court will hear an uninterrupted precise record of what the child was saying about the

\footnotetext{
${ }^{45}$ Ahern, Lyon, and Quas, "Young Children's Emerging Ability To Make False Statements."

${ }^{46}$ Mustaffa and Kamaliah, "Evidence by Child in Criminal Proceedings in Malaysian Courts: A Study on Post Ratification of Convention of Rights of Child."

${ }^{47}$ Mustaffa and Kamaliah.
} 
incident because their memory is still fresh and intact, as the incident just had happened. ${ }^{48}$

This is important to secure the acquittal of the innocent accused and secure convictions of those guilty. Thus, the suggestion is that there should be an additional section, for, i.e. s-6A of ECW 2007, to govern on the particular provision. The section is to allow video recorded during interrogation to be part of the evidence. It is good to take the testimony of a child during the interrogation stage because it is before the time they erased specific details from their memory and are confused by subsequent interference of adults or by their surroundings. Even though it contradicts the rule against hearsay, perhaps the law should also consider giving up the rigid observance of strict principles of evidence and its admissibility regarding children if it is the only way to ensure justice is upheld. ${ }^{49}$

The third procedure that needs to be improved is on the matter regarding the waiting room. There should be a provision that governs the separate waiting room. About this provision, the court shall ensure that the children are put in a secure and comfortable ambience during the giving of testimony in the court and before the giving of testimony. One of the possible ways is to have a separate waiting room explicitly designated for the child only. This is to avoid the child feeling uncomfortable when waiting for their turn while sitting with other adult witnesses. The fourth procedure is to have a separate entry or exit point for the children. This is important to protect the child from seeing other people involved in the criminal proceedings, subsequently disturbing the child and negatively affecting the child's testimony.

The last procedure that needs improvement is the court's power to clear the courtroom. It can be seen that ECW 2007 is silent on the court's power to remove the public in the gallery. Although Section 4 of the ECW 2007 allows for the setting of the screen, it is merely intended to obstruct the child's view from the accused and the public. Still, the child's mind is already notified and knowing the presence of the public in the gallery. For instance, in particular offences against decency and morality such as rape, the outrage of modesty or sexual assault, to name a few, the child victim is customarily called the most critical witness 38 . This will subsequently put the child into silence due to her dread and terror of the aftermath. Hence it does not serve justice. Other than that, say in the event where the child is the only witness available in a rape victim case, the court leaves no choice but to ask the child to narrate the full story of an incident in a very detailed manner. The child then may feel embarrassed and humiliated to narrate before the crowd in court.

Next, given in the situation where the child is a witness of a murder case, they may not tell everything that they know when they consciously knew of the presence of the accused's family in the courtroom. This is because the child is anxious, worried or distressed that they may get in trouble with the accused's family due to their testimony. In other words, the child may feel threatened and unsecured to say anything that favors the prosecution case. To solve this particular issue, it can be suggested that the court be bestowed with discretionary power to clear the public gallery whenever necessary. Thus a new specific Section must be included. This is in line with the objective of UNCRC 1989 to protect the administration of child justice in terms of procedures wherein the mental and emotional immaturity of a child involved is to be taken into account.

\section{Conclusion}

To conclude, it can be summarized that the law of evidence related to child witness protection and the procedures has gone through rapid development over the years. The courtroom could be an intimidating place for some people, even the adult, especially if the child witness is called to appear in court. Understandably, the previous adversarial system will cause trauma, confusion and become a stressful experience for the children who need to give statements as witnesses.

\footnotetext{
${ }^{48}$ Gothard, "The Admissibility of Evidence In Child Sexual Abuse Cases."

${ }^{49}$ Mustaffa and Kamaliah, "Evidence by Child in Criminal Proceedings in Malaysian Courts: A Study on Post Ratification of Convention of Rights of Child."
} 
The current procedures could have reasonably accommodated the children witnesses well with laws such as Evidence Act 1950, Evidence Child Act 2007, Child Act 2001 and Sexual Offences against Children Act 2017. However, the progression should not stop, and thus the methods of collecting child witness statements should be improved from time to time to accommodate the children and ensure that justice is fairly served.

It can be concluded that in the current position in law under s. 118 and 133A of the Evidence Act 1950, corroboration is not mandatory when the child gives sworn evidence in court. The judge thinks that the child can be a competent witness because they can understand the nature of speaking the truth and comprehend the questions posed to them. However, if otherwise, corroboration is required to support the evidence. A thorough comparison and contrast can also be analyzed from the perspective of Islamic evidence law and the Malaysia Evidence Act 1950 regarding the differences in the degree of proof, number of witnesses, etc.

It is pertinent to ensure that the governing laws, the standards of welfare officers and centres in aiding the judiciary are in continuous improvement so that the children, who are one of the most vulnerable groups in the society, can be protected. These attempts to improve measures will be in line with the teachings of Islam.

\section{REFERENCES}

Ahern, Elizabeth C., Thomas D. Lyon, and Jodi A. Quas. "Young Children's Emerging Ability To Make False Statements." Developmental Psychology 47, no. 1 (2011): 61-66. https://doi.org/10.1037/a0021272.

Bala, Nicholas, Kang Lee, R.C.L. Lindsay, and Victoria Talwar. "The Competency of Children to Testify: Psychological Research Informing Canadian Law Reform." International Journal of Children's Rights 18 (2010): 53-77. https://doi.org/10.1163/157181809X458544.

Blewer, Robyn. "Testing the Law and Testing a Child's Evidence: Nineteenth-Century Corroboration Reforms and Child Witness Testimony." Australian Historical Studies 51, no. 3 (2020): 279. https://doi.org/10.1080/1031461X.2019.1697304.

Caprioli, Sarah, and David A. Crenshaw. "The Culture of Silencing Child Victims of Sexual Abuse: Implications for Child Witnesses in Court." Journal of Humanistic Psychology 57, no. 2 (2016): 9. https://doi.org/10.1177/0022167815604442.

Gertner, Eric. "The Unsworn Evidence Of Children And Mutual Corroboration." Osgoode Hall Law Journal 16, no. 2 (1978): 34.

Gothard, Sol. "The Admissibility of Evidence In Child Sexual Abuse Cases." Child Welfare 66, no. 1 (1987): 13-24.

Keenan, Caroline, and Laura Hoyano. Child Abuse: Law and Policy Across Boundaries. Oxford: Oxford University Press, 2007.

Melton, G. B. “Children's Competency To Testify.” Law and Human Behavior 5, no. 1 (1981): 73-85.

Montaldo, Charles. "Child Witnesses: Honest but Less Reliable." ThoughtCo, 2019. https://www.thoughtco.com/child-witnesses-honest-but-less-reliable-972221.

Mustaffa, Aminuddin, and Salleh Kamaliah. "Evidence by Child in Criminal Proceedings in Malaysian Courts: A Study on Post Ratification of Convention of Rights of Child." Malaysian Current Law Journal 6 CLJ (2010): 1-27.

Nazeri, Norbani Mohamed. "Protecting Child Victims in Malaysia." In Support for Victims of Crime in Asia, edited by Wing-Cheong Chan, 1st ed., 291. Oxfordshire: Routledge Publication, 2008.

Omar, Habibah, Siva Barathi Marimuthu, and Mazlina Mahali. Law of Evidence in Malaysia. 
2nd ed. Selangor: Sweet \& Maxwell, 2020.

Powell, Martine B. "Improving the Reliability of Child Witness Testimony in Court: The Importance of Focusing on Questioning Techniques." Current Issues in Criminal Justice 17, no. 1 (2005): 137-43. https://doi.org/10.1080/10345329.2005.12036342.

Powell, Martine B., and Donald M. Thomson. "The Makings of a Reliable Interview with a Child Witness." Australian Educational and Developmental Psychologist 18, no. 2 (2001): 25-38. https://doi.org/10.1017/S081651220002839X.

Shukri, Mohd, Muhammad Hafiz, Muhammad Hassan, and Mohd Khairul Hisyam. "Should a Child Be Allowed to Give Evidence? The Position of Child Evidence under Civil and Islamic Laws in Malaysia." Munich Personal RePEc Archive, 2014, 1-24. https://mpra.ub.uni-muenchen.de/60173/1/MPRA_paper_60173.pdf.

Shukri, Muhammad Hafiz Mohd, and Mohd Khairul Hisyam Hassan. "Should a Child Be Allowed to Give Evidence? The Position of Child Evidence under Civil and Islamic Laws in Malaysia." Samarahan, 2014.

Welder, Andrea N. "Sexual Abuse Victimization and the Child Witness in Canada: Legal, Ethical, and Professional Issues for Psychologists." Canadian Psychology 41, no. 3 (2000): 160-73. https://doi.org/10.1037/h0086866. 